\title{
MINERALOGY OF THE CLAY FRACTION OF ALFISOLS IN TWO SLOPE CURVATURES. IV - SPATIAL CORRELATION WITH PHYSICAL PROPERTIES ${ }^{(1)}$
}

\author{
Livia Arantes Camargo ${ }^{(2)}$, José Marques Júnior ${ }^{(3)}$ \& Gener Tadeu Pereira ${ }^{(4)}$
}

\begin{abstract}
SUMMARY
Although the influence of clay mineralogy on soil physical properties has been widely studied, spatial relationships between these features in Alfisols have rarely been examined. The purpose of this work was to relate the clay minerals and physical properties of an Alfisol of sandstone origin in two slope curvatures. The crystallographic properties such as mean crystallite size (MCS) and width at half height (WHH) of hematite, goethite, kaolinite and gibbsite; contents of hematite and goethite; aluminium substitution (AS) and specific surface area (SSA) of hematite and goethite; the goethite/(goethite+hematite) and kaolinite/ (kaolinite+gibbsite) ratios; and the citrate/bicarbonate/dithionite extractable Fe $\left(\mathrm{Fe}_{\mathrm{d}}\right)$ were correlated with the soil physical properties through Pearson correlation coefficients and cross-semivariograms. The correlations found between aluminium substitution in goethite and the soil physical properties suggest that the degree of crystallinity of this mineral influences soil properties used as soil quality indicators. Thus, goethite with a high aluminium substitution resulted in large aggregate sizes and a high porosity, and also in a low bulk density and soil penetration resistance. The presence of highly crystalline gibbsite resulted in a high density and micropore content, as well as in smaller aggregates. Interpretation of the cross-semivariogram and classification of landscape compartments in terms of the spatial dependence pattern for the relief-dependent physical and mineralogical properties of the soil proved an effective supplementary method for assessing Pearson correlations between the soil physical and mineralogical properties.
\end{abstract}

Index terms: aggregates, mineral crystallinity, density, porosity, penetration resistance, cross-semivariogram.

(1) Part of the first author's dissertation. Received for publication on August 2, 2012 and approved on February 26, 2013.

${ }^{(2)}$ Doctoral student (FAPESP scholarship) of the postgraduate program in Agronomy (Soil Science) of FCAV/Jaboticabal, Universidade Estadual Paulista - UNESP, Via de acesso Prof. Paulo Donato Castellani, s/n. CEP 14884-900 Jaboticabal (SP), Brazil. E-mail: li_arantes@yahoo.com.br

(3) Prof. Dr., Soils and Fertilizers Department, FCAV/Jaboticabal - UNESP. E-mail: marques@fcav.unesp.br

(4) Prof. Dr., Exact Science Department, FCAV/Jaboticabal, UNESP. E-mail: genertp@fcav.unesp.br 


\title{
RESUMO: MINERALOGIA DA FRAÇÃO ARGILA DE UM ARGISSOLO EM CURVATURAS DO RELEVO. II - CORRELAÇÃO ESPECIAL COM ATRIBUTOS FÍSICOS
}

\begin{abstract}
A influência da mineralogia da fração argila nos atributos físicos do solo é reportada na literatura; porém, as relações espaciais entre esses atributos são escassas em se tratando de Argissolos. $O$ objetivo deste trabalho foi avaliar a correlação espacial entre os minerais da fração argila e atributos físicos de um Argissolo de origem arenítica. Os atributos mineralógicos como diâmetro médio do cristal (DMC); largura à meia altura (LMA) dos minerais hematita, goethita, caulinita e gibbsita; teor; substituição isomórfica (SI); área de superfície específica (ASE) dos minerais hematita e goethita; razão goethita / goethita+hematita); e razão caulinita / (caulinita+gibbsita) foram correlacionados com os atributos físicos por meio da correlação simples de Pearson e dos semivariogramas cruzados entre esses atributos. As relações encontradas entre a substituição isomórfica da goethita e os atributos físicos do solo permitiram inferir sobre o efeito da cristalinidade desse mineral nos atributos físicos do solo. Goethitas com altos valores de substituição isomórfica favoreceram a dimensão dos agregados e da porosidade; o contrário ocorreu com a densidade do solo (Ds) e resistência a penetração (RP). Gibbsitas de maior grau de cristalinidade favoreceram os maiores valores de densidade do solo e RP.
\end{abstract}

Termos de indexação: óxidos de ferro, caulinita, gibbsita, densidade, agregados, semivariograma cruzado.

\section{INTRODUCTION}

The importance of clay mineralogy for the maintenance of the soil physical quality has been recognized for a long time, especially in soils with low organic matter content, which are typical of tropical regions (Six et al., 2002; Duiker et al., 2003; Igwe et al., 2009; McBride et al., 2012). In fact, a number of early studies report a favorable effect of iron $(\mathrm{Fe})$ oxides on the clay fraction and on the soil physical properties (Lutz, 1936; Kroth \& Page, 1947; Chesters et al., 1957; Blackmore, 1973; Schwertmann \& Kämpf, 1985; Igwe et al., 1995, 2009; Camargo et al., 2008b), but some reported no such effect (Desphande et al., 1968; Borggaard, 1983). According to Duiker et al. (2003), the absence of correlation between the $\mathrm{Fe}$ oxyhydroxides contents and soil aggregation may result from the weaker influence of these contents than of crystallinity. Thus, according to Azevedo \& Bonumá (2004), poorly crystalline oxides act as cementing agents facilitating soil aggregation. Anda et al. (2008) and Camargo et al. (2008a) also found that low crystallinity of clay minerals in Oxisols had a positive impact on soil aggregation.

The minerals kaolinite and gibbsite are correlated with soil physical properties such as density and permeability, as well as with the integrity of soil aggregates (Pinheiro-Dick \& Schwertmann, 1996; Ferreira et al., 1999; Schaefer, 2001; Pedrotti et al., 2003; Camargo et al., 2008b). Silicon- mediated kaolinite can enhance the aggregating effect of oxides in soil (Cambier \& Picot, 1988).

However, first studies mostly focused on soils with high Fe contents, such as Oxisols, and had to be extended to soils with low Fe levels. Also, all studies used classical statistical techniques such as simple correlations or associations.

Correlations between soil properties can be derived from cross-semivariograms, which allow a determination of the structure of spatial dependence of one property based on others. By using this technique, Paz-González et al. (2000) identified differences in spatial correlations between organic matter and cation-exchange capacity, both in agricultural soils and soils under natural vegetation. Camargo et al. (2008b) used a cross-correlation method to examine the relationship between mineralogy and physical properties under the influence of landscape, and found a negative spatial correlation between the crystallinity of clay minerals and aggregate stability and size. According to Camargo et al. (2008a) and Souza et al. (2009), relief influences clay mineralogy and physical properties, and hence their spatial distribution in the landscape. This justifies the use of geostatistics to investigate their mutual relationships.

Recently, the relationship between clay mineralogy and soil physical properties has been used to explain soil erosion. For this purpose, understanding soil degradation requires studies of spatial relationships between clay mineralogy and soil physical properties. These relationships allow the prediction of the spatial distribution of physical soil properties, e.g., of soil aggregates (Camargo et al., 2008b), and to optimize soil sampling and management strategies Another important aspect is the role of mineralogy and aggregate stability in the dynamics of soil organic carbon; according to Rasmussen et al. (2005), these are the key properties governing 
the dynamics of carbon and its implications on climate change.

The objective of this study was to spatially correlate the crystallinity properties of the clay minerals goethite, hematite, kaolinite, and gibbsite, and the physical properties of Alfisols in slope curvatures.

\section{MATERIAL AND METHODS}

\section{Study area}

The study area was located in the municipality of Catanduva, in the north-west of the state of São Paulo, Brazil, (latitude $21^{\circ} 05^{\prime} 57.11^{\prime \prime} \mathrm{S}$, longitude $49^{\circ} 01^{\prime}$ 02.08" W, $503 \mathrm{~m}$ a.l.s.). The Aw climate (Köppen classification) of the region is hot humid, tropical, with dry winters, a mean annual rainfall of $1,350 \mathrm{~mm}$, a mean annual temperature of $23^{\circ} \mathrm{C}$, a mean maximum and minimum temperature of 22 and $18{ }^{\circ} \mathrm{C}$, respectively, and with a relative air humidity of $74 \%$. The primary vegetation is seasonal rain forest and Cerrado (Brazilian savannah). The current main land use is for sugarcane plantations with a green harvesting system (practice of cane burning and cutting when still green), in use for over 20 years.

The soil parent material is sandstone from the Bauru Group in the Adamantina Formation (IPT, 1981). This formation contains refined sediments (Almeida et al., 1980) and Si-rich and Fe-poor minerals (Suguio, 1973).

The area was characterized by aerial photography at a 1:35,000 scale, with topographic profiling and geomorphological and pedological field classification. The soil was classified as Typic Hapludalf (Soil Survey Staff, 1999) (Table 1). The slope curvatures were classified based on field measurements according to Troeh (1965), using an elaborate digital elevation model (DEM) (Figure 1). Two different morphological areas were observed: one with convex and the other with concave slope curvatures.
Soil samples were collected from the $0.0-0.2 \mathrm{~m}$ layer at intersection points on a $100 \times 100 \mathrm{~m}$ georeferenced grid, consisting of regularly spaced nodes $(10 \times 10 \mathrm{~m})$ at a representative location of each area.

\section{Clay mineralogy and soil physical properties}

Iron oxides were removed from the clay fraction by extraction with dithionite-citrate-bicarbonate (DCB) according to Mehra \& Jackson (1960) and analysed for kaolinite (Kt) and gibbsite (Gb). Iron oxides were determined by previously concentrating the clay fraction with iron oxides, using the method of Norrish \& Taylor (1961), modified by Kämpf \& Schwertmann (1982). X-ray diffraction patterns were obtained, using an equipment with a cobalt anode and an iron filter for hematite $(\mathrm{Hm})$ and goethite $(\mathrm{Gt})$ diffractions, and a copper anode and a nickel filter for $\mathrm{Kt}$ and $\mathrm{Gb}$ diffractions (K $\alpha$ radiation, $20 \mathrm{~mA}, 30 \mathrm{kV}$ ). A scanning speed of $1^{\circ} 2 \theta$ per min, and an amplitude of $23-49^{\circ}$ for hematite (012 and 110) and goethite (110 and 111), and $11-19^{\circ}$ for kaolinite (001) and gibbsite (002), were used.

Tables 2 and 3 show the mean values of the clay mineralogical and physical properties in the concave and convex areas. A more detailed description of the method used to characterize the physical and mineralogical properties was given by Camargo et al. (2010) and Camargo et al. (2013a), respectively.

Separated materials and stable aggregates were determined by the method of Kemper \& Chepil (1965). The aggregates retained on the $4.76 \mathrm{~mm}$ sieve were subjected to slow pre-wetting by atomization with distilled water and then mixed for $15 \mathrm{~min}$ in a set of sieves $(2.0,1.0,0.5,0.25,0.125$, and $0.105 \mathrm{~mm}$ mesh size) in a water-filled container. The results of the stable aggregate analyses were used to calculate the mean geometric diameter (MGD) and mean weighted diameter (MWD). In order to determine soil porosity (total porosity, macropores and micropores), undisturbed samples were saturated for $48 \mathrm{~h}$ in a tray filled with water

Table 1. Physical and chemical properties of horizons A + E and Bt in the two selected areas

\begin{tabular}{|c|c|c|c|c|c|c|c|c|c|c|c|c|c|c|}
\hline Hor. & Depth & Munsell color & FS & CS & Silt & Clay & $\mathrm{pH}\left(\mathrm{CaCl}_{2}\right)$ & $\mathbf{O M}$ & SB & CEC & BS & $\mathrm{SiO}_{2}$ & $\mathrm{Al}_{2} \mathbf{O}_{3}$ & $\mathrm{Fe}_{2} \mathrm{O}_{3}$ \\
\hline & $\mathrm{cm}$ & moist & 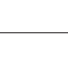 & \multicolumn{3}{|c|}{$\mathrm{g} \mathrm{kg}^{-1}$} & & $\mathrm{dm}^{-3}$ & \multicolumn{2}{|c|}{$\mathrm{mmol}_{\mathrm{c}} \mathrm{dm}^{-3}$} & $\%$ & $\longrightarrow$ & \multicolumn{2}{|l|}{$\mathrm{g} \mathrm{kg}^{-1}$} \\
\hline \multicolumn{15}{|c|}{ Profile of the concave area (Typic Hapludalf) } \\
\hline $\mathrm{A}+\mathrm{E}$ & 39 & $5 \mathrm{YR} 3 / 2$ & 698 & 149 & 106 & 47 & 4.8 & 13 & 29 & 52 & 56 & 12 & 35 & 20 \\
\hline $\mathrm{Bt}$ & 60 & $2.5 \mathrm{YR} 3 / 4$ & 627 & 113 & 187 & 165 & 4,2 & 10 & 36 & 63 & 57 & 20 & 115 & 27 \\
\hline \multicolumn{15}{|c|}{ Profile of the convex area (Typic Hapludalf) } \\
\hline $\mathrm{A}+\mathrm{E}$ & 30 & $5 Y R 3 / 3$ & 773 & 69 & 112 & 46 & 4.8 & 15 & 28 & 53 & 52 & 13 & 40 & 30 \\
\hline Bt & 60 & $2.5 \mathrm{YR} 4 / 4$ & 531 & 42 & 162 & 265 & 5.5 & 11 & 32 & 61 & 54 & 21 & 110 & 40 \\
\hline
\end{tabular}

Hor.: horizont; FS: fine sand; CS: coarse sand; OM: organic matter; SB: sum of bases; CEC: cation exchange capacity; BS: base saturation. 


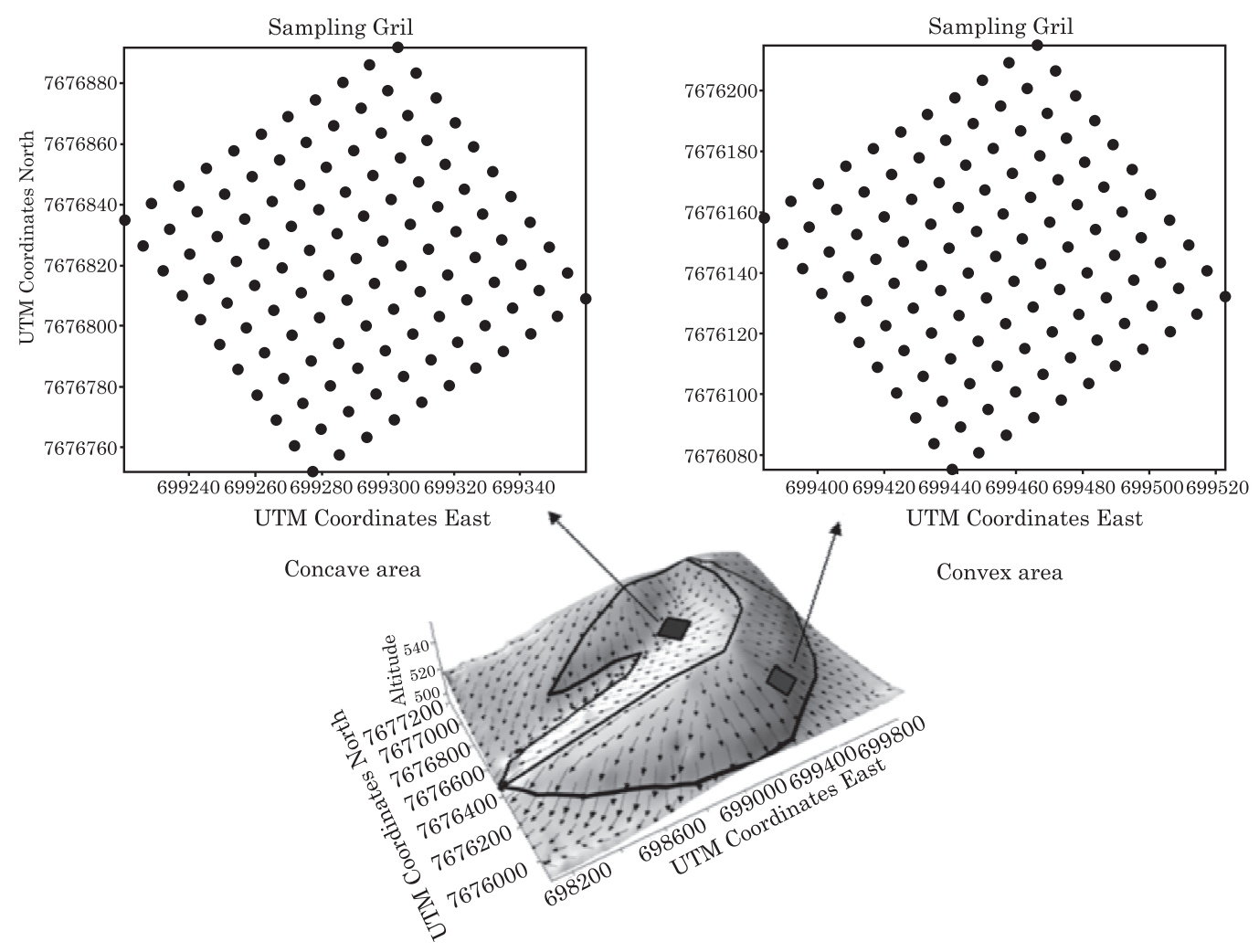

Figure 1. Digital elevation model (DEM) for the study area and sampling sites (+). The arrows in the center represent surface water flow.

Table 2. Mean values of the mineralogical properties studied in the convex and concave area

\begin{tabular}{|c|c|c|c|c|}
\hline \multicolumn{2}{|c|}{ Attribute } & \multicolumn{2}{|c|}{ Slope curvature ${ }^{(1)}$} & \multirow{2}{*}{ Student's $t$} \\
\hline & & Convex mean & Concave mean & \\
\hline \multirow{4}{*}{$\mathrm{WHH}^{(2)}$} & Gt & 0.52 & 0.54 & $1.51^{\mathrm{ns}}$ \\
\hline & $\mathrm{Hm}$ & 0.40 & 0.36 & $-5.96^{*}$ \\
\hline & $\mathrm{Kt}$ & 0.76 & 0.67 & $7.66^{*}$ \\
\hline & $\mathrm{Gb}$ & 0.31 & 0.29 & $4.48^{*}$ \\
\hline \multirow{4}{*}{$\mathrm{MCD}^{(3)}$} & Gt & 31.60 & 30.30 & $-0.87^{\mathrm{ns}}$ \\
\hline & $\mathrm{Hm}$ & 49.70 & 63.50 & $6.38^{*}$ \\
\hline & $\mathrm{Kt}$ & 14.53 & 17.42 & $-7.11^{*}$ \\
\hline & $\mathrm{Gb}$ & 74.50 & 84.00 & $-3.63^{*}$ \\
\hline \multirow{2}{*}{$\mathrm{AS}^{(4)}$} & Gt & 15.65 & 12.60 & $-3.44^{*}$ \\
\hline & $\mathrm{Hm}$ & 12.45 & 11.15 & $-2.70^{*}$ \\
\hline \multirow{2}{*}{$\mathrm{SSA}^{(5)}$} & Gt & 81.20 & 86.50 & $1.60^{\mathrm{ns}}$ \\
\hline & $\mathrm{Hm}$ & 36.31 & 33.69 & $-2.67 *$ \\
\hline \multirow{2}{*}{ Content $\left(\mathrm{g} \mathrm{kg}^{-1}\right)$} & $\mathrm{Gt}$ & 13.16 & 10.44 & $-5.92^{*}$ \\
\hline & $\mathrm{Hm}$ & 23.20 & 12.39 & $-20.03^{*}$ \\
\hline \multicolumn{2}{|l|}{$\mathrm{Fe}_{\mathrm{d}}{ }^{(6)}$} & 24.5 & 15.2 & $1.2^{*}$ \\
\hline \multicolumn{2}{|l|}{$\mathrm{Gt} /(\mathrm{Gt}+\mathrm{Hm})$} & 0.330 & 0.430 & $9.47 *$ \\
\hline \multicolumn{2}{|l|}{$\mathrm{Kt} /(\mathrm{Kt}+\mathrm{Gb})$} & 0.866 & 0.919 & $-12.91^{*}$ \\
\hline
\end{tabular}

${ }^{(1)}$ Adapted from Camargo et al. (2013a); ${ }^{(2)}$ Width at half height $\left({ }^{(} 20\right) ;{ }^{(3)}$ Mean crystallite dimension (nm); ${ }^{(4)}$ Aluminium substitution; ${ }^{(5)}$ Specific surface area; ${ }^{(6)} \mathrm{Fe}$ extracted by dithionite-citrate-bicarbonate $\left(\mathrm{g} \mathrm{kg}^{-1}\right)$, ${ }^{*}$ and ${ }^{\mathrm{ns}}$ : significant and not significant at $5 \%$ probability, respectively, by Student's $t$-test. Hm: Hematite, Gt: Goethite, Kt: Kaolinite, Gb: Gibbsite. 
Table 3. Mean weight diameter (MWD), mean geometric diameter (MGD), aggregates $>2 \mathrm{~mm}$ (>2 $\mathrm{mm})$, aggregates $1-2 \mathrm{~mm}(1-2 \mathrm{~mm})$, aggregates $<1 \mathrm{~mm}(<1 \mathrm{~mm})$, and soil penetration resistance (SPR) in the 0-0.2 m soil layer, at the 121 sampled points

\begin{tabular}{|c|c|c|c|}
\hline Attribute & lope curvature ${ }^{(1)}$ & Mean & Student's $t$ \\
\hline \multirow{2}{*}{ MWD (mm) } & Convex & 0.71 & $-3.17 *$ \\
\hline & Concave & 0.58 & \\
\hline \multirow{2}{*}{ MGD (mm) } & Convex & 0.65 & $-7.96^{*}$ \\
\hline & Concave & 0.56 & \\
\hline \multirow{2}{*}{$>2 \mathrm{~mm}(\%)$} & Convex & 14.20 & $-1.35^{\mathrm{ns}}$ \\
\hline & Concave & 12.56 & \\
\hline \multirow{2}{*}{$1-2 \mathrm{~mm}(\%)$} & Convex & 7.35 & $-10.43^{*}$ \\
\hline & Concave & 2.84 & \\
\hline \multirow{2}{*}{$<1 \mathrm{~mm}(\%)$} & Convex & 78.45 & $4.56^{*}$ \\
\hline & Concave & 84.60 & \\
\hline \multirow{2}{*}{ Micropores (\%) } & Convex & 22.75 & $-2.48 *$ \\
\hline & Concave & 21.52 & \\
\hline \multirow{2}{*}{ Macropores (\%) } & Convex & 14.31 & $-1.49^{\text {ns }}$ \\
\hline & Concave & 13.45 & \\
\hline \multirow{2}{*}{ Total porosity (\%) } & Convex & 37.04 & $-4.41^{*}$ \\
\hline & Concave & 35.03 & \\
\hline \multirow{2}{*}{ Bulk density $\left(\mathrm{g} \mathrm{cm}^{-3}\right)$} & Convex & 1.46 & $4.68^{*}$ \\
\hline & Concave & 1.52 & \\
\hline \multirow{2}{*}{$\mathrm{SPR}(\mathrm{MPa})$} & Convex & 1.77 & $8.41 *$ \\
\hline & Concave & 2.54 & \\
\hline
\end{tabular}

${ }^{(1)}$ Adapted from Camargo et al. (2010); ${ }^{*}$ and ${ }^{\text {ns: }}$ significant and not significant at $5 \%$ probability, respectively, by Student's $t$ test.

up to two-thirds of the height of the soil ring. After saturation, the samples were drained at an equivalent potential to $-0.006 \mathrm{MPa}$ on a tension table (Embrapa, 1997). These samples were also used to determine bulk density (Bd) with the volumetric ring method of Embrapa (1997), and moisture. The soil penetration resistance was determined in the field, using an IAA/Planalsucar impact penetrometer at each grid point and processing measurements according to Stolf (1991).

\section{Statistical analyses}

The correlation between soil properties was studied based on Pearson correlation coefficients and spatial correlation by cross-semivariograms for the specific variables with spatial dependence (Camargo et al., 2010, 2013a). Correlations were positive when the increase in one property caused an increase in the others and negative if an increase in one led to a decrease in the others (Bhatti et al., 1991; Ceddia et al., 2009; Camargo et al., 2013b). The geostatistical analysis was performed with software GS+ (Gamma Design Software, 1998).

\section{RESULTS AND DISCUSSION}

Tables 4 and 5 show the results of the Pearson correlation analysis between the soil physical and mineralogical properties in the convex and concave areas. An increased $\mathrm{Al}$ substitution (AS) in goethite (Gt) was positively correlated with larger aggregates and macropores, and had an opposite effect on microporosity, bulk density (Bd) and soil penetration resistance (SPR). This was a result of increased $\mathrm{Fe}$ for-Al substitution in the Gt structure, causing contraction of the unit cell by decreasing the crystallite size and hence the crystallinity of Gt (Norrish \& Taylor, 1961; Schwertmann \& Carlson, 1994; Friedl \& Schwertmann, 1996).

The increased specific surface area (SSA) resulting from the decreased crystallinity, which provides functional groups facilitating interactions between particles (Cornell \& Schwertmann, 1996) and retention of soil carbon (Anda et al., 2008), led to more stable aggregates.

Thus, Gt with high Al substitution probably increases aggregation in soil particles and consequently the number of macropores, which explains the negative effect on soil Bd and SPR (Table 2). Schahabi \& Schwertmann (1970) and Blackmore (1973) found a direct relationship between poorly crystalline synthetic goethites and aggregate stability. Duiker et al. (2003) and Igwe et al. (2009) previously found that poorly crystalline Fe oxides were the agents contributing most to aggregation in soils with low $\mathrm{OM}$ content (Table 1). The positive relationship between 1-2 $\mathrm{mm}$ aggregates and $\mathrm{AS}$ of $\mathrm{Hm}$ in the concave area had the same trends as observed for SI of Gt.

The negative correlation between citratebicarbonate-dithionite extractable $\mathrm{Fe}\left(\mathrm{Fe}_{\mathrm{d}}\right)$ and the mean geometric diameter (MGD) was significant. This was expected since $\mathrm{Fe}_{\mathrm{d}}$ is a measure of the content of crystalline iron oxides (Table 4). Similar results were previously obtained by Ghidin et al. (2006). WHH for gibbsite $(\mathrm{Gb})$ had a positive effect on 1-2 mm aggregates, similarly to MCD for Gb on Bd. The positive correlation between the $\mathrm{Kt} /(\mathrm{Kt}+\mathrm{Gb})$ ratio and micropores confirms the positive effect of Kt on the smaller aggregates and stability, consistent with previous results of Ferreira et al. (1999), Schaefer (2001) and Vitorino et al. (2003). According to Mbagwu \& Schwertmann (2006), Al oxides are more effective than $\mathrm{Fe}$ oxides for aggregation in some tropical soils.

Spatial correlation was determined by constructing a cross-semivariogram between the spatially dependent physical and mineralogical properties (Figure 2). Physical properties were used as main variables and mineralogical properties as auxiliary variables to assess the influence of clay mineralogy on soil physical properties.

Only in the convex area the soil physical properties were spatially dependent on the secondary variable 
(mineralogical properties). Although some physical and mineralogical properties in the concave area were spatially dependent (Camargo et al., 2010; 2013a), there was no spatial correlation between them. This was a result of most of the physical properties in the concave area without spatial dependence. Possibly, the increased spatial variability in physical and mineralogical properties in the concave area precluded the identification of spatial correlations between these properties, while the presence of other factors influenced the spatial distribution of physical properties to the detriment of mineralogical properties.

The spatially dependent properties included aggregates $<1 \mathrm{~mm} \times \mathrm{Fe}_{\mathrm{d}}, \mathrm{Fe}_{\mathrm{d}} \times$ micropores; aggregates $>2 \mathrm{~mm} \times \mathrm{Fe}_{\mathrm{d}}, \mathrm{Bd} \times \mathrm{MCD}$ for $\mathrm{Gb}$; aggregates $<1$ $\mathrm{mm} \times \mathrm{MCD}$ for $\mathrm{Gb}$, micropores $\times \mathrm{DMC}$ for $\mathrm{Gb}$, aggregates $<1 \mathrm{~mm} \times \mathrm{WHH}$ for $\mathrm{Gb}$; SPR $\times \mathrm{Hm}$ content and MWD $\times \mathrm{Hm}$ content (Figure 2 ). The models fitting the cross-semivariograms best were gaussian or spherical. The nugget effects of the crosssemivariograms for the physical properties were smaller than of the simple semivariograms for the same properties (Camargo et al., 2010, 2013a), indicating spatial continuity in these properties (PazGonzález et al., 2000).

The spatial correlations for aggregates $<1$ $\mathrm{mm} \times \mathrm{Fe}_{\mathrm{d}}$ and micropores $\times \mathrm{Fe}_{\mathrm{d}}$ in the crosssemivariograms were positive. This was also the case for $\mathrm{Bd}$ and MCD with Gb, with significant simple correlation. The spatial correlations for crosssemivariograms for aggregates $<1 \mathrm{~mm} \times \mathrm{MCD}$ for $\mathrm{Gb}$ also had positive spatial correlations.

Pedrotti et al. (2003) concluded that amorphous and poorly crystalline $\mathrm{Al}$ forms were more closely associated with physical properties, mainly with those related to soil particle aggregation, which explains the relationship observed in this study. Note that $\mathrm{WHH}$ for $\mathrm{Gb}$ was negatively correlated with aggregates $<1 \mathrm{~mm}$. This result illustrates the influence of Gb crystallinity in some soils, repeating that of Gt, as confirmed by the Pearson correlation coefficients.

The spatial correlation analysis also revealed a positive correlation of the Hm content with MWD and negative correlation with SPR, resulting from the higher levels of $\mathrm{Hm}$ than of Gt.

Table 4. Pearson correlation coefficients between iron oxide and soil physical properties

\begin{tabular}{|c|c|c|c|c|c|c|c|c|c|c|c|c|}
\hline & \multicolumn{2}{|c|}{ WHH $^{(\mathbf{1})}$} & \multicolumn{2}{|c|}{$\operatorname{MCD}^{(2)}$} & \multicolumn{2}{|c|}{$\mathbf{A S}^{(3)}$} & \multicolumn{2}{|c|}{ Contents } & \multicolumn{2}{|c|}{$\mathbf{S S A}^{(4)}$} & \multirow{2}{*}{$\mathbf{G} \mathbf{t} /(\mathbf{G} \mathbf{t}+\mathbf{H m})$} & \multirow{2}{*}{$F \mathbf{e}_{d}^{(5)}$} \\
\hline & Gt & Hm & Gt & Hm & Gt & Hm & Gt & Hm & Gt & Hm & & \\
\hline \multicolumn{13}{|c|}{ Convex area } \\
\hline $\mathrm{MWD}^{(6)}$ & 0.01 & -0.04 & 0.04 & 0.01 & 0.24 & 0.00 & -0.16 & -0.10 & 0.01 & -0.11 & -0.07 & -0.13 \\
\hline $\operatorname{MGD}^{(7)}$ & 0.04 & 0.01 & -0.03 & -0.06 & 0.17 & 0.00 & $-0.19 *$ & -0.13 & 0.04 & -0.04 & -0.07 & $-0.19 *$ \\
\hline$>2 \mathrm{~mm}^{(8)}$ & -0.01 & -0.05 & 0.06 & 0.01 & $0.26^{*}$ & 0.01 & -0.16 & -0.09 & -0.01 & -0.11 & -0.08 & -0.12 \\
\hline $1-2 \mathrm{~mm}^{(9)}$ & 0.06 & 0.08 & -0.10 & -0.11 & -0.03 & 0.05 & -0.07 & -0.04 & 0.06 & 0.08 & -0.01 & -0.12 \\
\hline$<1 \mathrm{~mm}^{(10)}$ & -0.02 & 0.01 & -0.01 & 0.04 & $-0.21^{*}$ & -0.03 & 0.16 & 0.09 & -0.01 & 0.06 & 0.07 & 0.16 \\
\hline Micro $^{(11)}$ & -0.01 & 0.15 & 0.04 & -0.17 & $-0.23^{*}$ & -0.10 & 0.07 & 0.12 & -0.01 & 0.06 & -0.03 & 0.18 \\
\hline Macro $^{(12)}$ & 0.00 & -0.16 & 0.01 & 0.16 & $0.18^{*}$ & -0.07 & 0.07 & -0.01 & 0.00 & $-0.19 *$ & 0.10 & -0.15 \\
\hline $\mathrm{TP}^{(13)}$ & 0.05 & -0.14 & 0.01 & 0.13 & 0.08 & -0.15 & 0.15 & 0.01 & 0.05 & -0.14 & 0.11 & 0.15 \\
\hline $\mathrm{Bd}^{(14)}$ & -0.17 & 0.14 & 0.10 & -0.17 & $-0.20 *$ & 0.16 & -0.08 & 0.14 & -0.17 & 0.09 & -0.13 & 0.01 \\
\hline $\mathrm{SPR}^{(15)}$ & 0.14 & $0.19 *$ & -0.11 & -0.13 & $-0.19 *$ & -0.03 & 0.08 & -0.14 & 0.14 & 0.13 & 0.17 & $-0.19 *$ \\
\hline \multicolumn{13}{|c|}{ Concave area } \\
\hline $\mathrm{MWD}^{(6)}$ & 0.01 & -0.02 & -0.05 & 0.04 & 0.02 & 0.13 & -0.09 & -0.02 & 0.08 & 0.01 & 0.07 & 0.03 \\
\hline $\mathrm{MGD}^{(7)}$ & -0.02 & -0.05 & -0.04 & 0.05 & -0.01 & 0.15 & -0.11 & -0.03 & 0.09 & -0.02 & 0.07 & 0.03 \\
\hline$>2 \mathrm{~mm}^{(8)}$ & 0.02 & -0.02 & -0.06 & 0.03 & 0.02 & 0.13 & -0.06 & 0.01 & 0.08 & 0.02 & 0.07 & 0.05 \\
\hline $1-2 \mathrm{~mm}^{(9)}$ & -0.15 & -0.06 & -0.03 & 0.05 & -0.18 & $0.25^{*}$ & 0.00 & 0.09 & 0.10 & -0.15 & -0.05 & 0.11 \\
\hline$<1 \mathrm{~mm}^{(10)}$ & 0.01 & 0.02 & 0.06 & -0.04 & 0.01 & -0.15 & 0.06 & -0.02 & -0.09 & 0.01 & -0.06 & -0.06 \\
\hline Micro $^{(11)}$ & -0.03 & 0.08 & -0.07 & -0.08 & -0.02 & 0.05 & $0.28^{*}$ & $0.20^{*}$ & -0.10 & -0.03 & 0.01 & 0.03 \\
\hline Macro $^{(12)}$ & 0.05 & -0.11 & 0.07 & 0.12 & 0.04 & -0.08 & $-0.25^{*}$ & -0.18 & 0.10 & 0.05 & 0.03 & -0.02 \\
\hline $\mathrm{TP}^{(13)}$ & 0.11 & -0.02 & -0.04 & 0.01 & 0.06 & -0.12 & -0.02 & -0.04 & 0.01 & 0.11 & 0.01 & -0.01 \\
\hline $\mathrm{Bd}^{(14)}$ & -0.09 & 0.02 & 0.09 & -0.01 & -0.11 & 0.08 & 0.12 & 0.11 & -0.02 & -0.09 & -0.04 & 0.04 \\
\hline $\mathrm{SPR}^{(15)}$ & -0.11 & 0.03 & 0.08 & -0.01 & -0.05 & -0.13 & 0.07 & 0.05 & -0.01 & -0.11 & -0.03 & 0.02 \\
\hline
\end{tabular}

${ }^{(1)}$ Width at half height; ${ }^{(2)}$ Mean crystallite size; ${ }^{(3)}$ Aluminium substitution; ${ }^{(4)}$ Specific surface area; ${ }^{(5)}$ Fe extracted by dithionitecitrate-bicarbonate; ${ }^{(6)}$ Mean weight diameter; ${ }^{(7)}$ Mean geometric diameter; ${ }^{(8)}$ Aggregates $>2 \mathrm{~mm},{ }^{(9)}$ Aggregates $1-2 \mathrm{~mm} ;{ }^{(10)}$ Aggregates $<1 \mathrm{~mm}$; ${ }^{(11)}$ Micropores; ${ }^{(12)}$ Macropores; ${ }^{(13)}$ Total porosity; ${ }^{(14)}$ Bulk density; ${ }^{(15)}$ Soil penetration resistance. Hm: Hematite, Gt: Goethite.

* significant at $5 \%$ probability. 
Table 5. Pearson correlation coefficients between kaolinite and gibbsite properties, and soil physical properties

\begin{tabular}{|c|c|c|c|c|c|}
\hline & \multicolumn{2}{|c|}{$\mathbf{W H H}^{(\mathbf{1})}$} & \multicolumn{2}{|c|}{$\operatorname{MCD}^{(2)}$} & \multirow{2}{*}{$\mathbf{K t} /(\mathbf{K t}+\mathbf{G} \mathbf{b})$} \\
\hline & $\mathbf{K t}$ & Gb & $\mathbf{K t}$ & $\mathbf{G b}$ & \\
\hline \multicolumn{6}{|c|}{ Convex area } \\
\hline $\mathrm{MWD}^{(3)}$ & 0.031 & 0.077 & -0.062 & -0.130 & 0.004 \\
\hline MGD $^{(4)}$ & -0.019 & 0.150 & -0.016 & -0.166 & -0.058 \\
\hline$>2 \mathrm{~mm}^{(5)}$ & 0.010 & 0.069 & -0.035 & -0.129 & -0.001 \\
\hline $1-2 \mathrm{~mm}^{(6)}$ & -0.003 & $0.216^{*}$ & -0.017 & -0.154 & 0.001 \\
\hline$<1 \mathrm{~mm}^{(7)}$ & -0.008 & 0.100 & 0.037 & 0.175 & 0.000 \\
\hline Micro $^{(8)}$ & 0.105 & -0.174 & -0.113 & 0.134 & $0.203^{*}$ \\
\hline Macro $^{(9)}$ & -0.009 & 0.154 & 0.015 & -0.130 & $0.230 *$ \\
\hline $\mathrm{TP}^{(10)}$ & 0.043 & 0.062 & -0.060 & -0.101 & -0.154 \\
\hline $\mathrm{Bd}^{(11)}$ & 0.056 & -0.108 & 0.081 & $0.180^{*}$ & 0.131 \\
\hline $\mathrm{SPR}^{(12)}$ & -0.091 & -0.128 & 0.121 & 0.166 & -0.000 \\
\hline \multicolumn{6}{|c|}{ Concave area } \\
\hline $\mathrm{MWD}^{(3)}$ & -0.185 & -0.119 & 0.179 & 0.146 & 0.072 \\
\hline $\mathrm{MGD}^{(4)}$ & 0.152 & -0.057 & 0.143 & 0.091 & 0.035 \\
\hline$>2 \mathrm{~mm}^{(5)}$ & $-0.199 *$ & -0.135 & 0.193 & 0.158 & 0.067 \\
\hline $1-2 \mathrm{~mm}^{(6)}$ & 0.076 & 0.043 & 0.034 & -0.02 & -0.076 \\
\hline$<1 \mathrm{~mm}^{(7)}$ & $0.197^{*}$ & 0.119 & -0.185 & -0.145 & -0.053 \\
\hline Micro $^{(8)}$ & -0.038 & -0.031 & 0.052 & -0.008 & -0.053 \\
\hline Macro $^{(9)}$ & 0.065 & -0.058 & -0.045 & 0.080 & 0.053 \\
\hline $\mathrm{TP}^{(10)}$ & -0.053 & -0.149 & 0.075 & 0.149 & 0.012 \\
\hline $\mathrm{Bd}^{(11)}$ & -0.079 & -0.009 & 0.031 & 0.011 & 0.071 \\
\hline $\mathrm{SPR}^{(12)}$ & -0.039 & 0.180 & 0.036 & $-0.197 *$ & -0.019 \\
\hline
\end{tabular}

${ }^{(1)}$ Width at half height; ${ }^{(2)}$ Mean crystallite size; ${ }^{(3)}$ Mean weight diameter; ${ }^{(4)}$ Mean geometric diameter; ${ }^{(5)}$ Aggregates $>2$ mm; ${ }^{(6)}$ Aggregates 1-2 mm; ${ }^{(7)}$ Aggregates <1 mm; ${ }^{(8)}$ Micropores; ${ }^{(9)}$ Macropores; ${ }^{(10)}$ Total porosity; ${ }^{(11)}$ Bulk density; ${ }^{(12)}$ Soil penetration resistance. Kt: Kaolinite; Gb: Gibbsite. * significant at $5 \%$ probability.

The influence of mineralogical properties on physical properties could only be assessed in the convex area, despite the intensive management practices typical of mechanized sugarcane cultivation in this area. In fact, although physical properties can easily be modified by soil management, the separation of landscape compartments, based on the spatial dependence pattern of the relief-dependent physical and mineralogical properties, allows the identification of relationships between these properties. This assessment technique increases the predictive ability for properties used as indicators of soil physical quality and to optimize soil sampling and management strategies.

\section{CONCLUSIONS}

1. The correlations found between the aluminium substitution of goethite (Gt) and soil physical properties suggest that Gt crystallinity affects physical properties, reflecting the soil quality. Thus, goethite with high aluminium substitution increases aggregate size and porosity, and decreases bulk density and soil penetration resistance.
2. Aluminium substitution of Gt and gibbsite crystallinity were the most relevant properties for the maintenance of the soil physical/structural quality, even in soils with low Fe levels and high proportions of kaolinite.

3. Analyzing the cross-semivariogram and separating landscape compartments via the spatial dependence pattern for relief-dependent physical and mineralogical properties can be an effective supplementary tool for assessing Pearson's correlation coefficient between the soil physical and mineralogical properties.

\section{ACKNOWLEDGEMENTS}

The Usina São Domingos is gratefully acknowledged for access to the study area and the Fundação de Amparo à Pesquisa do Estado de São Paulo (FAPESP) for a postgraduate scholarship to the first author (L.A.C.) and the Conselho Nacional de Desenvolvimento Científico e Tecnológico (CNPq) for Research Grant to the 2 nd and 3 rd authors. 


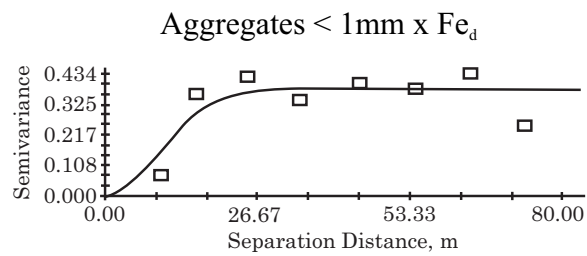

Gaussian model $(\mathrm{Co}=0.00100 ; \mathrm{Co}+\mathrm{C}=0.37600 ; \mathrm{Ao}=13.20 ;$ $\mathrm{r}^{2}=0.661 ; \mathrm{RSS}=0.0375$

Aggregates $>2 \mathrm{~mm} \times \mathrm{Fe}_{\mathrm{d}}$

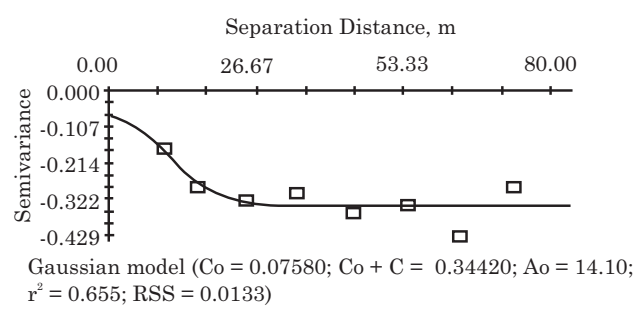

Aggregates $<1 \mathrm{~mm} \times \mathrm{MCD}$ of Gb

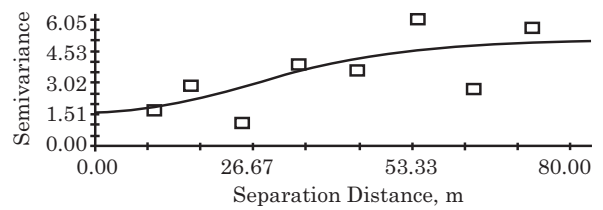

Gaussian model $(\mathrm{Co}=1.60000 ; \mathrm{Co}+\mathrm{C}=5.05300 ; \mathrm{Ao}=37.37$; $\left.\mathrm{r}^{2}=0.479 ; \mathrm{RSS}=11.4\right)$

Aggregates $<1 \mathrm{~mm}$ x WHH of Gb

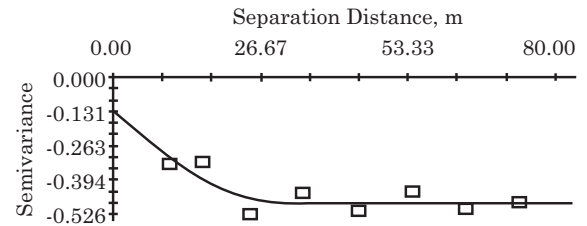

Spherical model $(\mathrm{Co}=0.13000 ; \mathrm{Co}+\mathrm{C}=-0.48100 ; \mathrm{Ao}=29.70$ $\mathrm{r}^{2}=0.689 ; \mathrm{RSS}=0.0135$

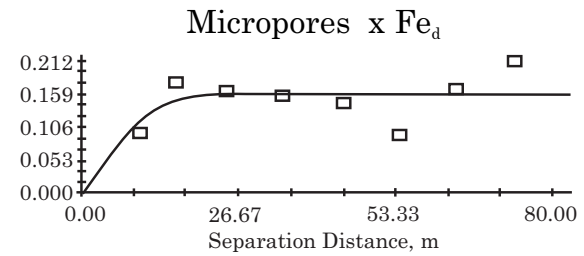

Spherical model $(\mathrm{Co}=0.00010 ; \mathrm{Co}+\mathrm{C}=0.15720 ; \mathrm{Ao}=19.10$; $\left.\mathrm{r}^{2}=0.256 ; \mathrm{RSS}=8.279 \mathrm{E}-03\right)$

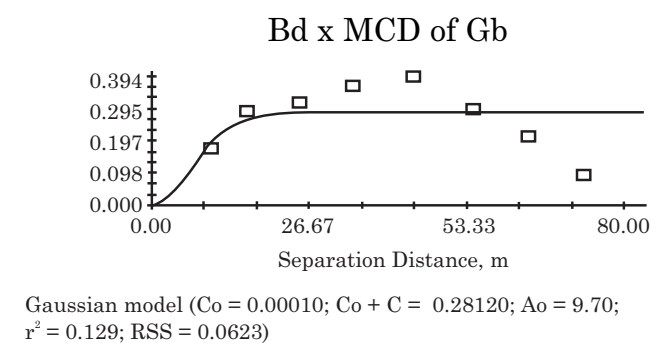

Micropores x MCD of Gb

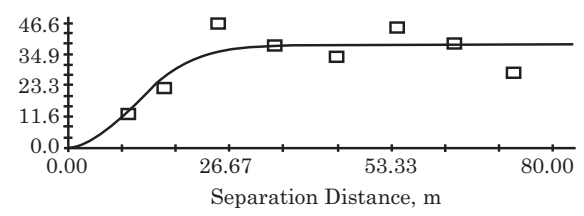

Gaussian model $(\mathrm{Co}=0.10000 ; \mathrm{Co}+\mathrm{C}=38.37000 ; \mathrm{Ao}=14.90$; $\mathrm{r}^{2}=0.687 ; \mathrm{RSS}=286$ )

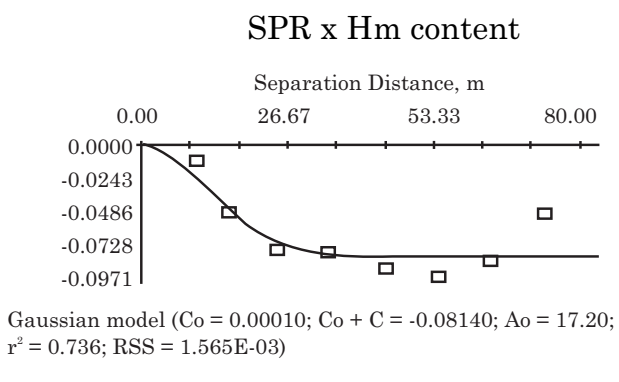

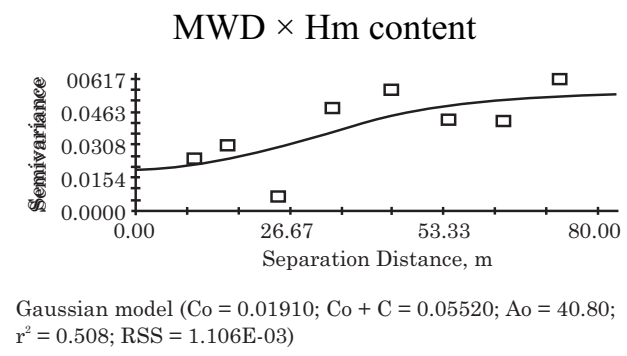

Figure 2. Cross-semivariograms for the study area. Fed: Fe extracted by dithionite-citrate-bicarbonate; MCD: mean crystallite dimension; WHH: width at half height; MWD: Mean weight diameter; Hm: Hematite; Gb: Gibbsite.

\section{LITERATURE CITED}

ALMEIDA, M.A.; STEIN, D.P.; MELO, M.S.; BISTRICHI, C.A.; PONÇANO, W.L.; HASUI, Y. \& ALMEIDA, F.F.M. Geologia do Oeste Paulista e áreas fronteiriças dos Estados de Mato Grosso do Sul e Paraná. In: CONGRESSO BRASILEIRO DE GEOLOGIA, 31., Camboriú, 1980. Anais... Camboriú: 1980. p.2799-2812.
ANDA, M.; SHAMSHUDDIN, J.; FAUZIAH, I.C. \& OMAR, S.R.S. Pore space and specific surface area of heavy clay Oxisols as affected by their mineralogy and organic matter. Soil Sci., 173:560-574, 2008.

AZEVEDO, A.C. \& BONUMÁ, A.S. Partículas coloidais, dispersão e agregação em Latossolos. Ci. Rural, 34:609$617,2004$. 
BHATTI, A.U.; MULLA, D.J.; KOEHLER, F.E. \& GURMANI, A.H. Identifying and removing spatial correlation from yield experiments. Soil Sci. Soc. Am. J., 55:1523-1528, 1991.

BLACKMORE, A.V. Aggregation of clay by the products of iron (III) hydrolysis. Austr. J. Soil Res., 11:75-85, 1973.

BORGGAARD, O.K. The influence of iron oxides on phosphate adsorption by soil. J. Soil Sci., 34:333-341, 1983.

CAMARGO L.A.; MARQUES JR., J. \& PEREIRA, G.T. Mineralogy of clay fraction of Alfisols in two slope curvatures. III. Spatial variability. R. Bras. Ci. Solo, 37:295$306,2013 \mathrm{a}$

CAMARGO L.A.; MARQUES JR., J. \& PEREIRA, G.T. Spatial correlation between the composition of the clay fraction and contents of available phosphorus of an Oxisol at hillslope scale. Catena, 100:100-106, 2013b.

CAMARGO, L.A.; MARQUES JR., J. \& PEREIRA, G.T. Spatial variability of attributes of an Alfisol under different hillslope curvatures. R. Bras. Ci. Solo, 34:617-630, 2010.

CAMARGO, L.A.; MARQUES JR, J.; PEREIRA, G.T. \& HORVAT, R.A. Variabilidade espacial de atributos mineralógicos de um Latossolo sob diferentes formas de relevo. I. Mineralogia da fração argila. R. Bras. Ci. Solo, 32:2269-2277, 2008a.

CAMARGO, L.A.; MARQUES JR, J.; PEREIRA, G.T. \& HORVAT, R.A. Variabilidade espacial de atributos mineralógicos de um Latossolo sob diferentes formas de relevo. II. Correlação espacial entre mineralogia e agregados. R. Bras. Ci. Solo, 32:2279-2288, 2008b.

CAMBIER, P. \& PICOT, C. Nature des liaisons kaolinite-oxyde de fer au sein des microagregats d'un sol ferralitique. Sci. Sol, 26:233-238, 1988.

CEDDIA, M.B.; CEDDIA, M.B.; VIEIRA, S.R.; VILLELA, A.L.O.; MOTA, L.S.; ANJOS, L.H.C. \& CARVALHO, D.F. Topography and spatial variability of soil physical properties. Sci. Agric., 66:338-352, 2009.

CHESTERS, G.; ATTOE, O.J. \& ALLEN, O.N. Soil aggregation in relation to various soil constituents. Soil Sci. Soc. Am. Proc., 21:272-277, 1957.

CORNELL, R.M. \& SCHWERTMANN, U. The iron oxides. Structure, properties, reactions, occurrence and uses. New York, Weinheim - VHC, 1996. 573p.

DESPHANDE, T.L.; GREENLAND, D.J. \& QUIRK, J.P. Changes in soil properties associated with the removal of iron and aluminium oxides. J. Soil Sci., 19:108-122, 1968.

DUIKER, S.W.; RHOTON, F.E.; TORRENT, J.; SMECK, N.E. \& LAL, R. Iron (hydr)oxide crystallinity effects on soil aggregation. Soil Sci. Soc. Am. J., 67:606-611, 2003.

EMPRESA BRASILEIRA DE PESQUISA AGROPECUÁRIA EMBRAPA. Manual de métodos de análise de solo. 2.ed. Rio de Janeiro, 1997. 212p.

FERREIRA, M.M.; FERNANDES, B. \& CURI, N. Influência da mineralogia da fração argila nas propriedades físicas de Latossolos da região Sudeste do Brasil. R. Bras. Ci. Solo, 23:515-524, 1999
FRIEDL, J. \& SCHWERTMANN, U. Aluminium influence on iron oxides. 18. The effect of $\mathrm{Al}$ substitution and crystal size magnetic hyperfine fields of natural goethites. Clay Miner., 31:455-464, 1996.

GAMMA DESIGN SOFTWARE. GS+: Geostatistics for the environmental sciences. Plainwell, Gamma Design Software, 1998

GHIDIN, A.A.; MELO, V.F.; LIMA, V.C. \& LIMA, J.M.J.C. Topossequências de Latossolos originados de rochas basálticas no Paraná. II. Relação entre mineralogia da fração argila e propriedades físicas dos solos. R. Bras. Ci. Solo, 30:307-319, 2006.

IGWE, C.A.; AKAMIGBO, F.O.R. \& MBAGWU, J.S.C. Physical properties of soils of southeastern Nigeria and the role of some aggregating agents in their stability. Soil Sci., 160:431-441, 1995.

IGWE, C.A.; ZAREI, M. \& STAHR, K. Colloidal stability in some tropical soils of southeastern Nigeria as affected by iron and aluminium oxides. Catena, 77:232-237, 2009.

INSTITUTO DE PESQUISAS TECNOLÓGICAS DO ESTADO DE SÃO PAULO - IPT. Mapa Geomorfológico do Estado de São Paulo. Escala 1:1.000.000. São Paulo, 1981

KÄMPF, N. \& SCHWERTMANN, U. Goethite and hematite in a climosequence in Southern Brazil and their application in classification of kaolinitic soils. Geoderma, 29:27-39, 1982.

KEMPER, W.D. \& CHEPIL, W.S. Size distribution of aggregates. In: BLACK, C.A.; EVANS, D.D.; WHITE, J.L.; ENSMINGER, L.E. \& CLARK, F.E., eds. Methods of soil analysis - Physical ad mineralogical properties, including statistics of measurement d sampling. Madison, American Society of Agronomy, 1965. p.499-510.

KROTH, E.M. \& PAGE, J.B. Aggregate formation in soils with special reference to cementing substances. Soil Sci. Soc. Am. Proc., 11:27-34, 1947.

LUTZ, J.F. The relation of free iron in the soil to aggregation. Soil Sci. Soc. Am. Proc., 1:43-45, 1936.

MBAGWU, J.S.C. \& SCHWERTMANN, U. Some factors affecting clay dispersion and aggregate stability in selected soils of Nigeria. Inter. Agrophys., 20:23-30, 2006.

McBRIDE, R.A.; SLESSOR, R.L. \& JOOSSE, P.J. Estimating the particle density of clay-rich soil with diverse mineralogy. Soil Sci. Soc. Am. J., 76:569:574, 2012.

MEHRA, O.P. \& JACKSON, M.L. Iron oxide removal from soils and clay by a dithionite-citrate system bulfered with sodium bicarbonate. Clays Clay Miner., 7:317-327, 1960.

NORRISH, K. \& TAYLOR, R.M. The isomorphous replacement of iron by aluminium in soil goethites. J. Soil Sci., 12:294306,1961 .

PAZ-GONZÁLEZ, A.; VIEIRA, S.R. \& CASTRO, M.T.T. The effect of cultivation on the spatial variability of selected properties of an umbric horizon. Geoderma, 97:273-292, 2000.

PEDROTTI, A.; FERREIRA, M.M.; CURI, N.; SILVA, M.L.N.; LIMA, J.M. \& CARVALHO, R. Relação entre atributos físicos, mineralogia da fração argila e formas de alumínio no solo. R. Bras. Ci. Solo, 27:1-9, 2003. 
PINHEIRO-DICK, D. \& SCHWERTMANN, U. Microaggregates from Oxisols and Inceptisols: dispersion through selective dissolution and physicochemical treatments. Geoderma, 74:49-63, 1996.

RASMUSSEN, C.; TORN, M.S. \& SOUTHARD, R.J. Mineral assemblage and aggregates control carbon dynamics in a California conifer forest. Soil Sci. Soc. Am. J., 69:1711$1721,2005$.

SCHAEFER, C.E.G.R. Brazilian Latosols and their B horizon microstructure as long-term biotic constructs. Austr. J. Soil Res., 39:909-926, 2001.

SCHAHABI, S. \& SCHWERTMANN, U. Der Einfluâ von synthetischen Eisenoxiden auf die Aggregation zweier Löâbödenhorizonte. Z. Pflanzenernähr, 125:193-204, 1970.

SCHWERTMANN, U. \& CARLSON, L. Aluminium influence on iron oxides: XVII. Unit-cell parameters and aluminium substitution of natural goethites. Soil Sci. Soc. Am. J., 58:256-261, 1994.

SCHWERTMANN, U.; KÄMPF, N. Properties of goethite and hematite in kaolinitic soils of Southern and Central Brazil. Soil Sci., 139:344-350, 1985.
SIX, J.; FELLER, C.; DENEF, K.; OGLE, S.M.; SÁ, J.C.M. \& ALBRECHT, A. Soil organic matter, biota and aggregation in temperate and tropical soils - Effects of no-tillage. Agronomie, 22:755-775, 2002.

SOIL SURVEY STAFF. Soil taxonomy: A basic system of soil classification for making and interpreting soil surveys. 2.ed. Washington, 1999. 869p.

SOUZA, Z.M.; MARQUES JR., J. \& PEREIRA, G.T. Spatial variability of the physical and mineralogical properties of the soil from the areas with variation in landscape shapes. Braz. Arch. Biol. Technol., 52:305-316, 2009.

STOLF, R. Teoria e teste experimental de fórmulas de transformação dos dados de penetrômetro de impacto em resistência do solo. R. Bras. Ci. Solo, 15:229-235, 1991.

SUGUIO, K. Introdução à sedimentologia. São Paulo, Edgard Blucher, 1973. 317p.

TROEH, F.R. Landform equations fitted to contour maps. Am. J. Sci., 263:616-627, 1965.

VITORINO, A.C.T.; FERREIRA, M.M.; CURI, N.; LIMA, J.M.; SILVA, M.L.N. \& MOTTA, P.E.F. Mineralogia, química e estabilidade de agregados do tamanho de silte de solos da região Sudeste do Brasil. Pesq. Agropec. Bras., 38:133141, 2003. 